\title{
Erratum to: Integration of the Continual System of Nonlinear Interaction Waves
}

\author{
Pham Loi Vu
}

Published online: 4 December 2009

(C) Springer Science+Business Media B.V. 2009

\section{Erratum to: Acta Appl Math \\ DOI 10.1007/s10440-008-9345-9}

The acknowledgment text towards the end of the paper should read:

Acknowledgements The author wishes to thank the referees for their valuable criticism. This work has been supported by the Vietnam National Foundation for Science and Technology Development (NAFOSTED).

The online version of the original article can be found under doi:10.1007/s10440-008-9345-9.

P.L. Vu $(\bowtie)$

Institute of Mechanics, Vietnam Academy of Science and Technology, 264 Doi Can Street, Hanoi, Vietnam

e-mail: plvu@imech.ac.vn 